\title{
Peculiarities of Life-Meaning Orientations of Mature People
}

\author{
Tatiana N. Sakharova* \\ Moscow Pedagogical State University \\ 1 Malaya Pirogovskaya Str., Moscow, 119435, Russia
}

Received 25.12.2018, received in revised form 21.01.2019, accepted 04.02.2019

The study of life-meaning orientations of mature people is described in the article. The author's definition of person's life-meaning orientations is given. The results of empiric study of the content of mature people's life-meaning orientations are considered. Adulthood is characterized by the author as a period of self-realization and possibility for the highest development of personality. The results of data cluster analysis are presented and the content of the four clusters are described. The author labels these clusters in accordance with their content. The attempt to identify the typology of mature people's life-meaning orientations has been made. Peculiarities of life-meaning orientation in adulthood are considered against modern social situation of development. These peculiarities are analyzed with due regard for different factors. Conclusions drawn by the author make it possible to create generalized socio-psychological portrait of the age group under study.

Keywords: maturity, person's life-meaning orientations, meaning of life.

Research area: psychology.

Citation: Sakharova, T.N. (2019). Peculiarities of life-meaning orientations of mature people. J. Sib. Fed. Univ. Humanit. soc. sci., 12(2), 217-230. DOI: 10.17516/1997-1370-0390.

\section{Maturity is a significant stage of ontogenesis}

Maturity is the most prolonged period of ontogenesis which is characterized by the tendency for achievement of the highest possible level of development of spiritual, intellectual and physical abilities (Ermolaeva, 2004). Uncertainty, crises, successes and failures, self-realization, self-knowledge, search of the Self, own meaning of life, ways to achieve it, joys and sorrows, changing life position, decisions and life without changes - all these are inherent for people in maturity. The main characteristic of development in maturity is minimal dependence on chronological age; it is determined

(C) Siberian Federal University. All rights reserved

* Corresponding author E-mail address: sakharova@mail.ru ORCID: 0000-0001-9688-2674

This work is licensed under a Creative Commons Attribution-NonCommercial 4.0 International License (CC BY-NC 4.0). 
by personal circumstances of man's life: occupation, attitudes, etc. Being the longest and significant period of man's life, maturity to-day becomes socio-psychological phenomenon which requires detailed examination. Person's life-meaning orientations as well as his/her peculiarities related to psychological characteristic of particular age can be a criterion for personality's development (beginning at adolescence).

\section{Objectives of the study}

The search of life meaning, namely, life meaning orientations of mature people is the objective of the study. The main task was to reveal peculiarities of life-meaning orientations of mature people. It is known that they can change and be different from the ones in adolescence, youth and old age. The process of searching and gaining the meaning of life is impossible without setting of certain attitude to oneself. Namely at this basis it is possible to satisfy man's need for self-realization. This need gives rise for the tendency to search and gain the meaning of life which specifies the path and ways of self-realization. The revelation of peculiarities of meaning sphere of mature persons as factors of certain aspects is the main question of the research.

Based on the above mentioned ideas, the following tasks of empiric research of life-meaning orientations of mature persons have been formulated:

1 - to diagnose and analyze life-meaning orientations of mature age persons;

2 - based on sample average ideas about life-meaning orientation to construct socio-psychological portrait of the age group under study.

\section{Meaning of life and life-meaning orientations of a person}

The problem of life meaning is an interdisciplinary one because meaning of life is one of the traditional problems for philosophy and theology. In fiction, the content of the concept is analyzed: what is the meaning of life, what meaning of life can be considered as veritable, kind, worth? In psychological literature the significance of psychological phenomenon of life meaning for a man is stressed as well. But the question about the meaning of life is outside the competence of psychology. As pointed out by D.A. Leont'ev, the issue about influence of meaning of life or experience of its deficiency as well as the problem of psychological reasons for its loss and ways of life meaning gaining are in the sphere of interests of psychology of personality (Leont'ev, 2003). In psychology meaning of life is studied in terms of factors that influence the formation of meaning of life in individual development and in what way already formed meaning of life or its absence affects person's life activity and consciousness. 
S.L. Rubinshtein and B.G. Anan'ev were the first in domestic psychology who addressed to life meaning issue. S.L. Rubinshtejn wrote that life path was certain integrity and at the same time consisted of phases each of which could be a turning point in person's life. Life path for S.L. Rubinshtein is not a sum of life events, separate actions, creative works. Life path is integral, continuous phenomenon.

Every person, in S.L. Rubinshtein's opinion, "has own history and even becomes an individual precisely because has his own life history" (Rubinshtein, 2004). It is important for S.L. Rubinshtein not only to define age stages but to consider the way each stage prepares the next one and affects it. Each stage plays an important role in life path but does not define it with inescapable fatality. The central problem for individual life is whether a person could become a subject of his own life. A person becomes the subject of his own life due to the capacity to solve his problems, to be responsible for his actions. A person becomes the subject of his own life in the way he defines ways of life contradictions' solving and realizes his responsibility for the consequences of such decision towards himself and other people.

\section{Meaning of resolving life contradictions}

Following the ideas of S.L. Rubinshtein, K.A. Abul'khanova-Slavskaya, considers that resolving of life contradictions favours person's development (Abul'khanovaSlavskaya, 1999). Resolving of life contradictions K.A. Abul'khanova-Slavskaya understands as relations between people. Socio-psychological and personal maturity of a man is characterized by the way of life contradictions' resolving: "The latter is manifested itself in ability to associate own individual peculiarities, own status, age resources, own pretentions with the demands of society and other people. The ability to realize this association we define as life strategy" (Abul'khanova-Slavskaya,1999).

K.A. Abul'khanova-Slavskaya (following S.L. Rubinshtein) proposes to study person's life path in its integrity, while life strategy should consist in disclosure and resolving of true causes of contradictions and not in escape through changes of life.

B.S. Bratus', in turn, thinks over meaning of life as "a vital need which is based on fundamental contradiction between boundedness (mortality) of individual being and universality of man's generic essence (Bratus', 1981).

\section{Meaning of life can be found}

The concept of life meaning is central in V. Frankl's theory. Man's desire to find and realize meaning of life is considered by V. Frankl as inborn motivation tendency 
that is inherent for all people and is the main mover of man's behavior and development. The lack of meaning in life is a cause for a number of mental diseases including specific "noogenic neurosis" and different types of delinquent behavior. Though the meaning of life is unique for every person, there are conceptual universals such as values that represent generalized typical senses. According to V. Frankl, a man under no circumstances could lose the meaning of life; life meaning could always be found (Frank1, 1990).

V. Frankl considers that a man could find the meaning of life by three ways:

1 - in a deed which is focused on achievement of socially significant goals;

2 - in experiencing of humanistic values;

3 - by taking certain position towards circumstances of own life.

Undoubtedly, meanings are rooted in being, they exist in objective reality but realization of objectively existing ontological meaning is always individual.

\section{Meaning of life influences person's vital activity and consciousness}

D.A. Leont'ev has contributed to study of psychology of meaning. He points out that complex and multisided reality of meanings in its different forms and manifestations is masked by the meaning concept (Leont'ev, 2003). Concerning life meaning phenomenon D.A. Leont'ev has marked that the latter in psychology is studied in terms of individual factors of life meaning formation and in what way meaning of life or its absence affects person's vital activity and consciousness. The problem of life meaning searching is important for a man at any stage of age development. Particular importance this problem plays in the period of "double crisis" - age and social. Modern state of society is characterized by breaking of its principles. That is why domestic psychologists pay grate attention to the problem of life meaning formation, its influence on man's destiny under the circumstances. Thus, researchers stressed its positive effect on man's life and person's formation while describing meaning of life.

\section{Meaning of life is a specific psychic formation}

V.E. Chudnovskij claims that meaning of life is not only a certain specific idea which is adopted and worked out by a man but specific mental formation which has its own specific character of origination; own stages of formation and, being stable and independent, can significantly impact man's life and his destiny (Chudnovskij, 2003). 
To study man's life meaning formation V.E. Chudnovskij identifies characteristics of this phenomenon which essence is in "emancipation from both and it starts to act as buffer as a system of checks and balances that forbids oneside submission to external and, at the same time, blocks transforming the human being into slave of his own needs, drives of immediate interests" (Chudnovskij, 2003). Discussing the issue of life meaning formation, V.E. Chudnovskij pays special attention to characteristics of so-called crisis, critical moments in age development and correlates its specific character with peculiarities of life meanings. In consideration of biological factors of age development, the author distinguishes two age periods - adolescents and aging.

\section{Significance of meaning of life as a psychological phenomenon}

V.E. Chudnovskij distinguishes two meanings of life meaning as a psychological phenomenon:

1 - essence, the main thing in the phenomenon;

2 - personal significance of the essence, the main thing, the fundamental.

Life meaning phenomenon includes these meanings and that essence, the main things prevails over minor, secondary. But to define life-meaning's "dominant" is only one aspect of searching meaning of life process. It is important to understand the extent to which the dominant is "productive" and to which extent it forwards positive development of a person. In this regard it is reasonable to bear in mind the adequacy of meaning of life as one of its main characteristics.

Two features of adequacy were identified by V.E. Chudnovskij:

1 - "realism" of life meaning, that is correspondence of meaning of life, on the one hand, to available, objective conditions that are necessary for its realization, and to man's individual capacities, from the other;

2 - "constructiveness" of life meaning, that is the rate of its positive (or negative) influence of the process of person's formation and successfulness of man's activity.

\section{Search of meaning of life and goals of own being}

In V. Frankl's opinion the search for the purpose of own being is inherent to thinking human being who provides own basic needs. Life meaning orientations of every person is a set of peculiar for a given person values and goals which he/she has chosen as fundamentals for own being. Specific character of this need is in uniqueness of its understanding by every person and hence, it is impossible to define existing 
cliché for the most successful goals of being, thus making difficulties for their study and development (Frankl, 1990).

\section{Motives that define meaning and happiness of life}

A.N. Leont'ev defines the level of hierarchy in activities and their motives as the most important parameters of a person. High level in motives' hierarchy means that a man tries on all his actions to the most important motive for him that is to the goal of life. This main motive is restricted in ones by the senseless goal of creating "gold state", for example, in others "extends to true human, does not separate a man but connects his life with the lives of others, with their well-being". In the latter case, the main motives of a man "are capable of creating inner psychological justification of its existence which constitutes meaning and happiness in life" (Leont'ev, 2005).

\section{The emergence of meaning in life through refraction of the world of others}

At the same time in L.I. Antsyferova's works it has been mentioned that formation of meaning of life is determined by man's attitude towards the past and the future and the way of refraction of other people worlds through attitude to oneself (Antsyferova, 2006).

G.L. Tul'chinskij examined three aspects of life meaning problem in his works:

1 - meaning of life as socio-ideological model of the due;

2 - as objective orientation of life activity which may be unconscious;

3 - as subjectively realized meaning (Tul'chinskij, 1985).

From A.A. Bodalev's point of view, problem of meaning of life is of particular relevance for people who are at extreme situation (stuttering, deaf-blindness) and who requires social rehabilitation (Bodalev, 1997). He wrote about the role of true values in formation of meaning of life and stressed that the search was connected inseparably with creative attitude to reality and the most complete realization of man's potential.

\section{Reason for the narrowing of meaning of life}

Exploring phases of life path B.G. Anan'ev reveals that their peculiarities are determined not only by social factors but by meaning of life as well. From this position he has analyzed so called "paradox of man's life termination" the essence of which is that "dying" of forms of human existence starts earlier than "physical senility" from the old ages (Anan'ev, 2001). Under the conditions of social isolation there comes breaking, narrowing of meaning of life that result in person's degradation. 


\section{Life-meaning orientations and principles of life}

Discussion of studies that have been devoted to peculiarities of life-meaning orientations can be a basis for characterizing of person's life-meaning orientations as conscious and generalized principles of man's life and his life goals. Psychological way of experiencing life includes not only guidelines but evaluation of own achievements and comparison them with own individual criteria as well. It is considered that lifemeaning orientations itself are subject to age dynamics and their content is associated with peculiarities of social environment, nurturing, individual needs and desires. It is essential that social-and-historical conditions which are the background for person's development and functioning are the factors for system of life-meaning orientations changing. Socio-economic, political, ideological transformations of society result in transformation of value system, moral standards in society, social groups and particular person. Meaning of life as a subject for psychological study in the structure of personality should be considered from different angles. The analysis of studies has revealed that along with theoretical one empirical research of peculiarities of formation and manifestation of meaning of life for a man in modern society are also needed. To-day due to social instability the main part of mature people faces the problem of identification and search for life sense. In this regard the problem of life meaning orientations of mature-age people and modeling of generalized psychological portrait of the given age group in modern social-and-historical conditions becomes topical.

\section{Psychological characteristic of maturity}

As it was pointed out, maturity is the longest for the majority of people period of life that is characterized by the tendency towards achievement of the highest level of development of spiritual, intellectual and physical abilities. Maturity is considered to be the period of person's flourishing when a man can realize his own potential and achieve the greatest successes in all life spheres. It is time for execution of human predestination in professional, public activity and in the continuation of bloodline. Professional activity and family relations are the main areas of life in maturity. Social situation of development in this period is associated with active involvement in the sphere of social production, formation of family, manifestation of own individuality in children's upbringing, creativity, relations with people in labour activity. Adult person strive to occupy a key position in society (Kulagina, Kolutskiy, 2001).

In C.G. Jung's opinion, man in maturity should shift from extensive to intensive position, from tendency for expansion and attainments of life space to concentration 
on own Self. And then the second half of life will provide the achievement of wisdom, culmination in creative activity and not the neurosis and despair. C.G. Jung stressed the idea that man's soul in the second half of life changes deeply. But unfortunately, the majority of people is unaware of possibility of these transformations and enter unprepared into the second half of life (Jung, 2006). Mature person is capable of development. It is associated with the process of socialization. Socialization of an adult is in its nature self-development through choices: who to be, what to be, with whom to be, etc. - that is choice of own psychological image, health or disease and way of life in the whole.

\section{Maturity is a choice between productivity and inertness}

In the author's opinion position of E. Erikson who considers the choice between productivity and inertness that characterize progressive and regressive line in development to be the main problem of maturity is quite interesting (Erikson, 1996). Productivity in E. Erikson's conception is connected with care "about people, results and ideas that are of man's interest". The lack of productivity, inertness results in preoccupation of oneself, own needs.

\section{Maturity is the period of awareness of responsibility for the content of own life towards oneself and others}

Understandings of responsibility for the content of own life towards oneself and others is the main peculiarity of maturity. Development of adult person requires getting rid of unreasonable maximalism that is typical for adolescence and youth, balancing and multidimensional approach to life problems including professional activity. Realization of life plan or life conception causes person's development in adulthood.

\section{Methods of research}

Questionnaire "Test of life meaning orientations" by D.A. Leont'ev was used in the research (Leont'ev, 2006). Adult people aged 35-45 years participated in the research. The total number of 368 (184 females and 184 males) residents of Moscow, Lyubertsy and Zheleznodorozhnyj of Moscow region, Smolensk and Vyaz'ma participated in the research. At the moment of research all respondents were working, almost all of them were married, half of them have children. Almost two thirds of the respondents have higher education and one thirds have secondary and specialized education. Cluster and comparative analysis were used for data processing. Student's t-test was used as well. 


\section{Cluster analysis of the results of the study of mature people life meaning orientations}

The task of the research was to arrange the data into clusters. For this purpose grouping of the participants has been done. The task of the analysis was to divide the sample into homogenous groups. Method of automatic classification was used for this purpose. The method made it possible to classify the subjects taking into account a great number of characteristics. Hierarchical cluster analysis was used. Statistical data processing was made by means of EXCEL, Statistics and SPSS programs.

Four obvious groups were specified in analysis thus forming the basis for hypothesis about a number of clusters.

Four types of subjects were defined according to four clusters:

- the first type (1 cluster) consists of 96 persons;

- the second type (2 cluster) consists of 160 persons;

- the third type (3 cluster) consists of 76 persons;

- the fourth type (4 cluster) consists of 32 persons.

Comparative analysis of life meaning index by Student's t-test was used to define differences between subjects. Differences were found to be statistically significant.

\section{Characteristic of types of life meaning orientations of mature-age people}

The analysis of the research data makes it possible to define clusters and give them conditional names. Further analysis includes content characteristic of identified types.

The first type called "conformists" brings together 96 persons $(26 \%$ of the respondents). Males with spesialized education, married, with children constitute the majority of this cluster. Calmness is the main thing for this type. First and foremost these people are oriented towards comfort, family well-being and everyday goods. They prefer comfortable way of life, leisurely, calm and unhurried. The main motto of these people is "Slow and steady wins the race". "Life without problems" in the sense of well being and absence of hardships is typical for these people. Adventures and extreme emotions are not to them. In communication with other people they stick to conformal behavior. They do not like disputes and quarrels. "Do not hurt" live in a way to be respected, be as everybody, do not do harm to others are the main principles of their life. This type of people is satisfied with their lives. They do not want to change their past. In the future they do not wish to burden themselves with unnecessary deeds, want to live without problems. They tend to do everything 
"properly", mostly they are not able to express their feelings spontaneously and immediately, they are oriented towards sobriety, practicalness and rational approach to problem solving. These people are obligatory and always do everything they have promised, but would do nothing beyond their reason. In life, as it was mentioned above, these people are conformists. They are satisfied with their social, material etc. status. They do not want to change anything in their lives because any changes may damage their "ideal" model of life.

The second type called "humanists" brings together 160 persons ( $44 \%$ of the sample). Females with higher education, with children constitute the majority of this cluster. People of this type appreciated the successes and possibility of active cognition of the world. They are full of energy. They identify their goals and intentions. Humane social orientation when their own happiness is associated with the good for others is inherent for these people. Deeds for the benefits of others are typical for them.

These people consider their past as productive and sensible, life in the present is interesting, full of emotions and understanding of future goals make the life meaningful, oriented towards time perspective. This type is characterized by high indices on Locus-control - Self, and Locus-control-Life. In life these people are not afraid of changes especially if this would result in good for family or his/herself. They are sure that they control their lives though they do not reject the fact that is not necessarily dependent on their desire. They are ready to make efforts to obtain the desired outcomes. Plans of these people are based on actual facts in the present and are supported by personal responsibility for their realization. Life style of these people forwards emotional richness of life and it is full of meanings. These people have an interest for life and desire to live it eventfully but at the same time eventfulness should not be beyond of line because they are calm persons in the whole. "To move mountains" for the sake of emotions is not for them. Sobriety and rational approach in problems solving are typical for them. As it is mentioned above, these people are fond of comfort and calmness. Everyday deeds give them the pleasure but in this they may seem routine to them. Upon the whole the life of this type of people has developed in the way they wish. In future they would like to do what they want to but do not have time in the present.

The third type called "optimists" brings together 76 persons ( $27 \%$ of the sample). Males and females constitute this cluster in equal parts. All of them have higher education, married without children. It is important for this type of people to do 
something useful in life. These people are optimists. It is important for them to feel their significance to others. They are self-confident and purposeful. They always try to move high and never stop on the achieved. Movement is a key to success for these people. In majority these people are full of energy; life for them is exciting and fascinating. People of this type clearly know what they want. They have clear goals and intentions towards any deeds. Their life is sensible. Every day for them is different. These people consider that their life is exactly they wanted; at the same time they believe that they still have a lot of unrealized where they've got to get to and worth living for. The world does not make them feel uncomfortable and confused. The majority of these people is responsible and always does what they are asked to and even more. They believe that they control their own lives and no socio-economic, political and other factors can prevent them from achieving their goals. These people highly appreciate success and possibility of active cognition of the world.

The fourth type called "fatalists" brings together 32 persons ( $9 \%$ of the sample). Males with specialized education, half of them do not have children constitute this factor. People of this type consider that their life is full of routine events. It is calm, comfortable and mainly is uninteresting. They do not like to burden themselves with troubles and live "from Monday to Friday". Day-to-day deeds do not satisfy them. Most of these people do not decide about life plans and goals and believe that they still have a lot of time. The surrounding world scares theses people. They are not confident in their future. They consider that the world does not depend on them and crises, social and political factors hinder their well-being. They are always looking for an excuse for their mistakes, do not inclined to blame themselves and plead circumstances. Dissatisfaction with the previous part of life is typical for these people. The majority of the respondents from this cluster would like to change their past. They wish to live their future without care or a worry. They prefer calmness in their lives. In communication with other people they stick to conformal behavior.

Personal meanings for these people are without orientation and time perspective. Besides they demonstrate lack of control over own life, fatalism and belief that man's life is beyond of conscious control, freedom of choice is illusory and it is unreasonable to plan future.

Thus four clusters have been obtained in the study, but in case there were more participants under study the number of clusters might be another and their characteristics might be different. But even with this number of participants the results of the research could be applied for life meaning orientations of mature people. 


\section{The results of empiric study of person's life meaning orientations}

The obtained results make it possible to draw a conclusion about influence of historical conditions on formation and development of every person. The results of the study reflect peculiarities of life-meaning orientations of a person from certain historical and social formation (Ermolaeva, 2004) and differ from the ones in different time periods (thus, unlike the studies of other scientists conducted a decade ago, gender differences in the content of life-meaning orientations in our study are not so obvious).

In line with A.N. Leont'ev our understanding of personal meaning as attitudes to the objects for which person's activity is realized is reflected in the content of lifemeaning orientations of mature people (Leont'ev, 1983). Due to special character of life activity and psychological peculiarities of the group under study, family and professional activity are such objects (spheres) for mature people. However, although mature person is oriented towards socio-economic, political and cultural conditions of life and in accordance to the latter manifests him/herself as a social unit he/she at the same time realizes as an unique individual (Muhina, 2017). Just that, in our opinion, explains the existence of four types as well as qualitative differences in the content of respondents' answers in the empiric research.

The results of the study make it possible on the basis on the sample average concepts about life meaning orientations to create generalized socio-psychological portrait of the age group under study and to draw conclusions that life-meaning orientations of mature people have some peculiar features:

- they are in the sphere of family and professional interests;

- represent existing life values and tasks for development;

- orientation towards results of life, satisfaction with self-realization level are the most marked tendency in life-meaning orientations;

- four groups of subjects have been revealed in the result of clustering; they were called "conformists", "humanists", "optimists" and "fatalists" and reflects general tendencies of the given age group.

More precise study of the content of mature people life-meaning orientations and comparison them with other age groups will be the object of future researches in the field.

\section{Acknowledgments}

The author is particularly grateful for all people of mature age who participated in the study. 


\section{References}

Abul'khanova-Slavskaya, K.A. (1991). Strategiya zhizni [Strategy of life]. M., Mysl', 229 p.

Anan'ev, B.G. (2001). Chelovek kak predmet poznaniya [Man as a subject of cognition]. SPb., Piter, $288 \mathrm{p}$.

Ancyferova, L.I. (2006). Razvitie lichnosti $i$ problemy gerontopsihologii [Development of personality and problems of gerontopsychology]. M., RAS Institute of Psychology Publishing House, 512 p.

Bodalev, A.A. (1997). Smysl zhizni i akme cheloveka. Sootnoshenie «budnichnogo» i «vysshego» Ya [Meaning of life and man's acme. Correlation of "everyday" and "higher" Self]. In Psihologo-pedagogicheskie i filosofskie aspekty smysla zhizni (materialy 1-2 simpoziumov) [Psychological-and-pedagogical and philosophical aspects of meaning of life (materials of 1-2 symposia)]. M., 5-8.

Bratus', B.S. (1981). K izucheniyu smyslovoj sfery lichnosti [On study of person's meaning sphere]. In Vestnik. Mosk. un-ta. Seriya 14. Psihologiya [Herald of MSU. Series 14. Psychology], 10-17.

Chudnovskij, V.E. (2003). Psihologicheskie sostavlyayushchie optimal'nogo smysla zhizni [Psychological components of optimal meaning of life]. In Voprosy psihologii [Questions of psychology], 3, 12-16.

Erikson, E. (1996). Identichnost': krizis i yunost' [Identity: crisis and youth]. M., Progress, $342 \mathrm{p}$.

Ermolaeva, M.V. (2004). Psihologiya zrelogo i pozdnego vozrastov v voprosah $i$ otvetah [Psychology of mature age in questions and answers]. M., MPSI Publishing House, $280 \mathrm{p}$.

Frankl, V. (1990). Chelovek v poiskah smysla [Man in search on meaning]. M., Progress, $372 \mathrm{p}$.

Jung, C.G. (2006). Problemy dushi nashego vremeni [Problems of our-time soul]. M., RAS Institute of Psychology Publishing House, 281 p.

Kulagina, I.Yu., Kolutskiy, V.N. (2001). Vozrastnaya psihologiya: polnyj zhiznennyj cikl razvitiya cheloveka [Age psychology: full life cycle of man's development]. M. TC Sfera, $464 \mathrm{p}$.

Leont'ev, A.N. (1983). Izbrannye psihologicheskie proizvedeniya [Selected psychological works]. M., Pedagogika, $320 \mathrm{p}$.

Leont'ev, A.N. (2005). Deyatel'nost'. Soznanie. Lichnost' [Activity. Consciousness. Personality]. M., Smysl, Akademia, 352 p. 
Leont'ev, D.A. (2003). Psihologiya smysla [Psychology of meaning]. M., Smysl, $487 \mathrm{p}$.

Leont'ev, D.A. (2006). Test smyslozhizennyh orientacij (SZhO) [Test life-meaning orientations]. M., Smysl, 18 p.

Muhina, V.S. (2017). Lichnost': Mify i Real'nost' (Al'ternativnyj vzglyad. Sistemnyj podhod. Innovacionnye aspekty) [Personality: Myths and Reality (Alternative view. System approach. Innovation aspects)]. M., Nacional'nyi knizhnyi centr, 1088 p.

Rubinshtein, S.L. (2004). Osnovy obshchej psihologii [Fundamentals of general psychology], 4-izd. SPb, Piter, 720 p.

Tul'chinskij, G.L. (1985). V kakom smysle vozmozhna teoriya smysla [In what sense theory of meaning is possible]. In Filosofskie osnovaniya nauchnoj teorii [Philosophical foundations of scientific theory]. Novosibirsk, Nauka, 108-127.

\section{Особенности смысложизненных ориентаций людей зрелого возраста}

T.H. Сахарова

Московский педагогический государственный университет Россия, 119435, Москва, ул. Малая Пироговская, 1

В статье описывается исследование смысложизненных ориентаций людей зрелого возраста. Дается авторское определение понятия «смысложизненные ориентации личности». Рассматриваются результаты эмпирического исследования содержания смысложизненных ориентаций людей зрелого возраста. Зрельй возраст характеризуется автором как период самореализации и возможности наивысшего развития личности человека. Приводятся результаты кластерного анализа полученных данных и описывается содержание четырех выделенных кластеров, которым автор дает название в соответствии с содержанием. Делается попытка выявления типологии смысложизненных ориентаций личности людей зрелого возраста. В статье особенности смысловой сферы личности в зрелости рассматриваются с учетом современной социальной ситуации развития. Особенности смысловой сферы личности в зрелом возрасте анализируются с учетом различных факторов. Сделанные автором выводы позволяют построить обобщенный соииально-психологический портрет изучаемой возрастной группьl.

Ключевые слова: зрелость, смысложизненные ориентации личности, смысл жизни.

Научная специальность: 19.00.00 - психологические науки. 